\title{
Pengaruh Rekrutmen Dan Kompensasi Terhadap Kinerja Karyawan Pada PT. Sinergi Inti Pelangi
}

\author{
${ }^{1}$ Rahmi Hermawati, Septi Indriyani \\ Dosen Fakultas Ekonomi Universitas Pamulang \\ ${ }^{1}$ Email :rahmi_herma@yahoo.com
}

\begin{abstract}
ABSTRAK
Penelitian ini bertujuan untuk mengetahui seberapa besar Pengaruh Rekrutmen terhadap Kinerja Karyawan, untuk mengetahui seberapa besar pengaruh kompensasi terhadap kinerja karyawan dan seberapa besar pengaruh dampak gaya rekrutmen dan kompensasi secara simultan terhadap kinerja karyawan.

Metode yang digunakan dalam penelitian ini adalah metode deskripsi dengan menggunakan pendekatan kuantitatif. Populasi dan sampel yang diteliti berjumlah 50 responden yang terdiri dari staf dan karyawan PT Sinergi Inti Pelangi dan penulis mengambil sampel dari seluruh populasi, dengan metode uji validitas, uji reliabilitas, uji asumsi klasik, uji normalitas, uji mulcholinearity, uji heteroskedastisitas, analisis uji regresi linier berganda, uji T (uji parsial), uji F (uji simultan) dan uji koefisien determinasi

Berdasarkan hasil penelitian, kesimpulan yang dapat penulis buat adalah sebagai berikut: (1) hasil yang diperoleh dari F yang dihitung adalah 41.491 dengan signifikansi 0.000. Sedangkan nilai $F$ tabel pada tingkat kepercayaan 95\% $(\alpha=5 \%)$ harus 3,20. Itu berarti, rekrutmen (X1) dan Kompensasi (X2) secara kolektif memiliki pengaruh yang sangat signifikan terhadap kinerja dengan Kinerja karyawan yang diperoleh dengan koefisien determinasi (R2) sebesar 0,555 akan menjadi pengaruh variabel independen lainnya yang tidak akan diteliti dalam penelitian ini.
\end{abstract}

\section{Kata Kunci: Rekrutmen, Kompensasi, Kinerja}




\section{PENDAHULUAN}

Di era globalisasi dan serba digital seperti sekarang ini, yang diiringi dengan revolusi industri 4.0 serta persaingan yang sangat ketat, menuntut setiap perusahaan untuk memperbaiki hal-hal yang terkait dengan performa perusahaan. Oleh karena, hal-hal yang harus di perbaiki adalah di semua aspek, khususnya pada sumber daya manusia (SDM) karena SDM merupakan aset yang paling penting dan berharga pada perusahaan, artinya setiap perusahaan yang ingin bertahan dan berkembang harus meningkatkan keefektifan dan keefisiensinan setiap sumber daya yang dimiliki termasuk SDM serta sistem mengelolanya. Sejauh apapun kemajuan perusahaan atau orga-nisasi tidak akan terlepas dari peran sumber daya manusianya.

Keberadaan sumber daya manusia di dalam suatu perusahaan memegang peranan sangat penting. Tenaga kerja memiliki po-tensi yang besar untuk menjalankan aktivitas perusahaan. Potensi setiap sumber daya manusia yang ada dalam perusahaan harus dapat dimanfaatkan dengan sebaik-baiknya sehingga mampu memberikan output yang optimal. Keberadaan SDM itu sendiri tidak luput dari berbagai proses pencarian SDM yang sering kita dengar yaitu rekrutmen.

Melalui proses-proses tersebut, karyawan diharapkan akan lebih memaksimalkan tanggung jawab atas pekerjaan mereka karena para karyawan telah terbekali oleh pendidikan dan pelatihan yang tentu berkaitan dengan implementasi kerja mere-ka. Sedangkan pemberian kompensasi, ling-kungan kerja yang baik serta pemberian motivasi pada dasarnya adalah hak para karyawan dan merupakan kewajiban dari pihak perusahaan untuk mendukung kontri-busi para karyawannya dalam rangka men-capai tujuan yang telah ditentukan. Oleh karena itu rekrutmen sangat membantu peru-sahaan untuk dapat men-dapat mencapai kinerja baik bagi perusahaan itu sendiri maupun bagi karyawan yang ada dalam perusahaan itu.

Selain faktor rekrutmen yang sudah dijabarkan diatas faktor kompensasi juga merupakan faktor yang sangat penting untuk meningkatkan kinerja karyawan di sebuah organisasi atau perusahaan. Menurut Hasibuan kompensasi (2017:117) adalah se-mua pendapatan yang berbentuk uang, barang langsung atau tidak langsung yang diterima karyawan sebagai imbalan atas jasa yang diberikan kepada perusahaan. Balas jasa yang diberikan untuk meningkatkan kinerja para tenaga kerja atau para karyawan. Para karyawan akan lebih termotivasi untuk melakukan tanggung jawab atas pekerjaan mereka apabila perusahaan mengerti dan memperhatikan betul akan kebutuhan para karyawan yang pada dasarnya adalah mere-ka bekerja untuk mendapatkan uang, dalam hal ini berbentuk gaji. Setiap anggota dari suatu organisasi mempunyai kepentingan dan tujuan sendiri ketika bergabung pada organisasi tersebut, bagi sebagian karyawan harapan untuk mendapatkan uang adalah satu-satunya alasan untuk bekerja, namun yang lain berpendapat bahwa uang hanyalah salah satu dari banyak kebutuhan yang terpenuhi melalui kerja.

Sebagaimana penjelasan di atas maka pelayanan adalah kunci utama keber-hasilan perusahaan, terutama perusahaan yang bergerak dibidang jasa seperti PT. Sinergi Inti Pelangi, untuk mempertahankan pela-yanan yang berkualitas tidak lepas dari peran SDM yang memiliki kinerja yang berkualitas. Usaha untuk mempertahankan dan meningkatkan kinerja kerja karyawannya adalah bagaimana cara merekrut dan menyeleksi karyawan yang kompeten di bi-dangnya. 
Dari tahun 2006 sampai sekarang PT. Sinergi Inti Pelangi telah mengalami pasang surut dalam bisnisnya, namun hal ini tidak menjadi hambatan bagi PT. Sinergi Inti Pelangi untuk terus berkompetisi, penye-diaan tenaga kerja yang siap untuk di supply ke perusahaan (eksternal) ataupun untuk internal, kunci utama untuk bersaing dengan kompetitor maka proses rekrutmen dan seleksi yang efektif dan efisien perlu di kembangkan untuk pemenuhan (fullfill) kuota permintaan dari klien dan internal. Maka banyak cara yang digunakan untuk mendapatkan source database kandidat yang nantinya akan disediakan.

Di PT. Sinergi Inti Pelangi proses rekrutmen diawali dengan permintaan user ke bagian rekrutmen. Kemudian bagian rekrutmen akan memantau dan mengecek database kandidat yang ada sekaligus memposting iklan di berbagai sosial media. Setelah ada kandidat yang sesuai dengan kualifikasi didapatkan, kandidat akan di undang untuk datang interview di kantor. Kandidat akan mengikuti tahapan perekrutan mulai dari interview sampai penanda-tanganan surat perjanjian kerja atau working agreement dengan kompensasi dan benefit peraturanperaturan, yang disepakati, sesuai dengan SOP (Standard Operasional Proce-dure) yang ada di PT. Sinergi Inti Pelangi.

Walaupun semua sudah dilakukan secara tertulis, akan tetapi terkadang terdapat hambatan dalam proses rekrutmen seperti para calon karyawan yang melamar tidak sesuai dengan kualifikasi yang diharapkan, walupun proses perekrutan sudah dilakukan dengan SOP yang telah ditetapkan. Di sisi lain pelamar mempunyai ekspektasi atau harapan lebih terhadap kompensasi yang akan diberikan perusa-haan, tetapi setelah masuk dan bekerja mereka merasakan kompensasi yang diberikan tidak sebanding dengan tugas dan tanggung jawab yang mereka berikan. Berikut dibawah ini merupakan data karyawan yang sudah di rekrut di PT. Sinergi Inti Pelangi :

Tabel 1.1

\section{Data Karyawan Baru}

\begin{tabular}{|c|c|c|c|c|c|c|}
\hline Tahun & Posisi Vacant & Level & $\begin{array}{l}\text { Target } \\
\text { Fulfill }\end{array}$ & Closing & (\%) & Remark \\
\hline 2015 & \begin{tabular}{|l|l|}
$\begin{array}{l}\text { Supervisor } \\
\text { Sulawesi }\end{array}$ & area \\
\end{tabular} & Supervisor & $05 / 03 / 15$ & 05/03/15 & $100 \%$ & Achieve \\
\hline \multirow{3}{*}{2016} & \begin{tabular}{|l|l|}
$\begin{array}{l}\text { Supervisor } \\
\text { Sumatera }\end{array}$ & area \\
\end{tabular} & Supervisor & $10 / 08 / 16$ & $04 / 09 / 16$ & $90 \%$ & No Achieve \\
\hline & \begin{tabular}{|l|l|}
$\begin{array}{l}\text { Staf Administrasi } \\
\text { area Jawa Timur }\end{array}$ \\
\end{tabular} & Staf & 15/07/16 & $17 / 07 / 16$ & $98 \%$ & No Achieve \\
\hline & \begin{tabular}{|lr} 
Staf & Recruitment \\
area Jakarta
\end{tabular} & Staf & $02 / 09 / 16$ & $02 / 09 / 16$ & $100 \%$ & Achieve \\
\hline \multirow{4}{*}{2017} & \begin{tabular}{|l|} 
Manager \\
Operasional \\
\end{tabular} & Manager & $10 / 01 / 17$ & $18 / 01 / 17$ & $97 \%$ & Achieve \\
\hline & \begin{tabular}{|l|l|}
$\begin{array}{l}\text { Supervisor } \\
\text { Jawa Tengah }\end{array}$ & area \\
\end{tabular} & Supervisor & 21/02/17 & $21 / 02 / 17$ & $100 \%$ & Achieve \\
\hline & \begin{tabular}{|l|} 
Staf Information \\
Technology (IT)
\end{tabular} & Staf & $22 / 05 / 17$ & $22 / 05 / 17$ & $100 \%$ & Achieve \\
\hline & $\begin{array}{l}\text { Staf Administrasi } \\
\text { Support Finance and } \\
\text { Acccounting area } \\
\text { Jakarta }\end{array}$ & Staf & $30 / 10 / 17$ & 25/11/17 & $90 \%$ & No Achieve \\
\hline
\end{tabular}

Sumber : PT. Sinergi Inti Pelangi

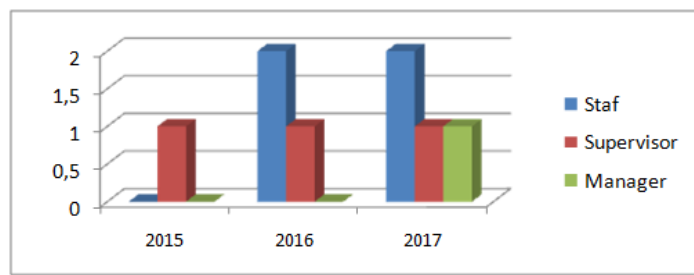

Sumber : PT. Sinergi Inti Pelangi

Grafik 1.1

Data Karyawan Baru

Dari tabel dan grafik 1.1 diatas menun-jukkan jumlah karyawan yang direkrut tiap tahun jumlahnya berbeda dan posisi lo-wongan pekerjaan setiap tahunnya meningkat. Berawal dari tahun 2015 terlihat pada tabel jumlah permintaan hanya satu orang untuk satu posisi yaitu di level supervisor, tahun 2016 mengalami permin-taan yang meningkat sebanyak tiga orang untuk tiga posisi dimana permintaan tersebut juga yaitu di level supervisor dan staf, dan terakhir pada tahun 2017 semakin meningkat ada empat permintaan yang harus dipenuhi dimana permintaan di tahun ini ada permintaan untuk level manager, supervisor, dan staf. Posisi kosong yang banyak artinya posisi tersebut harus segera diisi melalui proses rekrutmen agar kegiatan perusahaan dapat 
tetap berjalan dengan baik dan tidak terbengkalai.

Permintaan pada PT. Sinergi Inti Pelangi di tiap level pun berbeda-beda, paling banyak karyawan yang direkrut untuk dipenuhi yaitu untuk level staf dibandingkan dengan level supervisor dan manager. Dengan demikian jelas terlihat berapa banyak permintaan karyawan yang dibutuh-kan PT. Sinergi Inti Pelangi memenuhi posisi yang kosong.

Pemenuhan karyawan sangat erat hubungannya dengan kompensasi yang akan diberikan oleh organisasi ke karyawan. Kompensasi merupakan semua imbalan yang diterima oleh seorang pekerja atas jasa atau hasil kerjanya pada sebuah organisasi/ perusahaan. Imbalan tersebut dapat berupa uang ataupun barang, baik langsung ataupun tidak langsung, yang diberikan oleh sebuah organisasi atas hasil kerja/ jasa pekerja tersebut pada organisasi/ perusahaan.

Dibawah ini juga disajikan tabel yang berisi data kompensasi karyawan di PT. Sinergi Inti Pelangi dari beberapa tahun terakhir yang menggambarkan adanya gap atau ketidaksesuaian dengan Upah Minimum Provinsi (UMP). Tabel dibawah ini menya-jikan range perolehan gaji karyawan di tiap level yang ada di PT. Sinergi Inti Pelangi.

\section{Tabel 1.2}

Data Kompensasi Karyawan

\begin{tabular}{|c|c|c|c|c|c|c|c|c|c|}
\hline \multirow[b]{2}{*}{ Level } & \multicolumn{3}{|c|}{2015} & \multicolumn{3}{|c|}{2016} & \multicolumn{3}{|c|}{2017} \\
\hline & $\begin{array}{c}\text { Range } \\
\text { Gaji (dlm } \\
\text { jutaan) }\end{array}$ & $\begin{array}{l}\text { UMP } \\
\text { (dlm } \\
\text { jutaan) }\end{array}$ & Gap & $\begin{array}{c}\text { Range } \\
\text { Gaji (dlm } \\
\text { jutaan) }\end{array}$ & \begin{tabular}{|c} 
UMPP \\
(dlm \\
jutaan)
\end{tabular} & Gap & $\begin{array}{c}\text { Range } \\
\text { Gaji (dlm } \\
\text { jutaan) }\end{array}$ & $\begin{array}{c}\text { UMP } \\
\text { (dlm } \\
\text { jutaan) }\end{array}$ & Gap \\
\hline Manager & 05-Jul & 2,6 & $287 \%$ & 07-Oct & 3,1 & $370 \%$ & Oct-15 & 3,3 & $484 \%$ \\
\hline \begin{tabular}{|l|} 
Asisten \\
Manager
\end{tabular} & 04-Jun & 2,6 & $246 \%$ & 06-Aug & 3,1 & $296 \%$ & 08-Sep & 3,3 & $290 \%$ \\
\hline Supervisor & 04-May & 2,6 & $205 \%$ & 06-Aug & 3,1 & $296 \%$ & 08-Sep & 3,3 & $290 \%$ \\
\hline Staff & Jan- 22 & 2,6 & $90 \%$ & $1,5-3,1$ & 3,1 & $96 \%$ & $1,5-3,3$ & 3,3 & $97 \%$ \\
\hline
\end{tabular}

Sumber : PT. Sinergi Inti Pelangi

Berdasarkan tabel 1.2 diatas, jika digambarkan dengan sebuah grafik akan semakin terlihat adanya gap atau ketidaksesuaian kompensasi yang diterima oleh karyawan PT. Sinergi Inti Pelangi dalam tiga tahun terakhir, maka grafiknya akan nampak sebagai berikut :

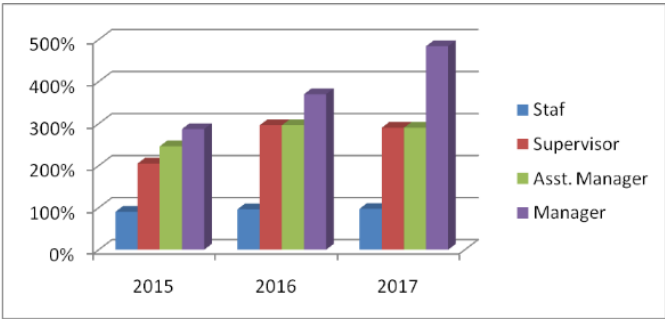

Sumber : PT. Sinergi Inti Pelangi

Grafik 1.2

Data Kompensasi Karyawan

Dari tabel 1.2 diatas yang bersumber dari PT. Sinergi Inti Pelangi, kompensasi karyawan dapat dilihat bahwa ada karyawan yang belum menerima kompensasi sesuai dengan upah minimum yang telah ditetapkan terutama pada level staf. Tahun 2015 untuk karyawan level staf belum menerima kompensasi yang sesuai, tahun 2016 belum ada penyesuaian bahkan di tahun 2017 masih ada karyawan yang belum menerima kompensasi sesuai dengan yang telah ditetapkan, terlihat jelas untuk kompensasi yang di terima oleh karyawan selama tiga tahun terakhir belum sesuai. Terlihat pada tahun 2015 untuk level staf hanya mencapai $90 \%$, tahun 2016 mengalami kenaikan sebesar 96\%, dan tahun 2017 sebesar 97\%. Dari uraian selama tiga tahun terakhir belum ada yang mencapai $100 \%$ dan kompensasi yang diterima belum sesuai dengan yang telah ditetapkan.

Dua hal yang sangat penting yaitu rekrutmen dan kompensasi tidak lepas halnya dengan Kinerja Karyawan, ini sangat berdampak pada ujung atau hasil akhir dari seorang karyawan. Kinerja Karyawan meru-pakan hasil kerja secara kualitas dan kuan-titas yang dicapai oleh seorang pegawai dalam melaksanakan tugasnya sesuai dengan tanggung jawab yang diberikan kepadanya. 
Dibawah ini juga disajikan tabel yang berisi data Kinerja Karyawan di PT. Sinergi Inti Pelangi dari beberapa tahun terakhir yang menggambarkan adanya penurunan performance karyawan. Tabel dibawah ini menyajikan nilai rata-rata yang di nilai melalui form evaluasi karyawan atau appraisal di PT. Sinergi Inti Pelangi.

Tabel 1.3

Data Kinerja Karyawan

\begin{tabular}{|c|c|c|c|c|}
\hline \multirow{3}{*}{ No } & \multirow{3}{*}{ Aspek } & \multicolumn{3}{|c|}{ TAHUN } \\
\hline & & 2015 & 2016 & 2017 \\
\hline & & Total (\%) & Total (\%) & Total (\%) \\
\hline 1 & Kualitas Kerja & 80 & 112 & 94 \\
\hline 2 & Kuantitas Kerja & 97 & 70 & 50 \\
\hline 3 & Inisiatif & 87 & 78 & 88 \\
\hline 4 & Disiplin & 100 & 88 & 73 \\
\hline 5 & Tanggung Jawab & 100 & 90 & 90 \\
\hline 6 & Motivasi & 95 & 100 & 100 \\
\hline 7 & Kerjasama & 70 & 67 & 67 \\
\hline 8 & Pemahaman terhadap tugas & 78 & 70 & 70 \\
\hline 9 & Penyesuaian Diri & 90 & 99 & 99 \\
\hline 10 & Kepemimpinan *) & 100 & 100 & 100 \\
\hline 11 & Pemecahan Masalah *) & 100 & 100 & 100 \\
\hline 12 & Pengambilan Keputusan *) & 100 & 100 & 100 \\
\hline & RATA-RATA & 91 & 90 & 86 \\
\hline
\end{tabular}

Sumber : PT. Sinergi Inti Pelangi

Dari data tabel 1.3 diatas yang telah disajikan, jika digambarkan dengan sebuah grafik agar semakin terlihat menurunnya Kinerja Karyawan pada PT. Sinergi Inti Pelangi selama tiga tahun terakhir yaitu tahun 2015, 2016, dan 2017, maka grafiknya sebagai berikut :

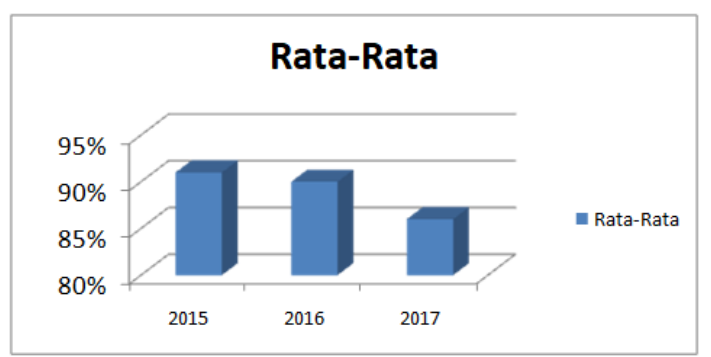

Sumber : PT. Sinergi Inti Pelangi

\section{Grafik 1.3}

\section{Data Kinerja Karyawan}

Dari tabel 1.3 diatas yang bersumber dari PT. Sinergi Inti Pelangi dapat dilihat bahwa kinerja karyawan dalam tiga tahun terakhir mengalami penurunan. Tahun 2015 performance karyawan berada pada angka 91\%, tahun 2016 mengalami penurunan sekitar $1 \%$ menjadi $90 \%$, dan di tahun ketiga mencapai $86 \%$. Terlihat jelas untuk kinerja karyawan sangat berpengaruh terhadap performance perusahaan secara kesulu-ruhan.

Menyadari betapa pentingnya makna rekrut-men dan kompensasi dalam sebuah organisasi dan berdasarkan latar belakang diatas, maka penulis sangat tertarik untuk melakukan penelitian yang berkaitan dengan rekrutmen dan kompensasi yang ber-pengaruh terhadap kinerja karyawan. Sehingga penulis menetapkan judul skripsi ini yaitu "Pengaruh Rekrutmen dan Kompensasi Terhadap Kinerja Karyawan Pada PT. Sinergi Inti Pelangi”.

\section{TINJAUAN PUSTAKA}

\section{A. Pengertian Rekrutmen}

Rekrutmen merupakan suatu cara mengambil keputusan perencanaan manaje-men sumber daya manusia mengenai jumlah karyawan yang dibutuhkan, kapan diperlu-kan, serta kriteria apa saja yang diperlukan dalam suatu organisasi. Rekrutmen pada dasarnya merupakan usaha mengisi jabatan atau pekerjaan yang kosong di lingkungan suatu organisasi atau perusahan, untuk itu ada dua sumber tenaga kerja yakni sumber dari luar (eksternal) organisasi dan sumber dari dalam (internal) organisasi.

Penarikan (rekrutmen) karyawan me-rupakan suatu proses atau tindakan yang dilakukan oleh organisasi untuk mendapat-kan tambahan karyawan melalui berbagai tahapan yang mencakup identifikasi dan evaluasi sumber-sumber penarikan tenaga kerja, menentukan kebutuhan tenaga kerja, proses seleksi, penempatan, dan orientasi tenaga kerja. Penarikan karyawan bertujuan untuk menyediakan karyawan yang cukup 
agar manajemen dapat memilih karyawan yang memenuhi kualifikasi yang mereka perlukan di perusahaan (Mathis: 2002).

Rekrutmen yang efektif memerlukan tersedianya informasi yang akurat dan berkesinambungan mengenai jumlah dan kualifikasi individu yang diperlukan untuk melaksanakan berbagai pekerjaan dalam perusahaan. Aktifitas rekrutmen akan me-nyisihkan pelamar yang kurang tepat dan memfokuskan kemampuannya pada calon yang akan dipanggil kembali. Aktifitas rekrutmen dapat membengun opini publik yang menguntungkan dengan cara mempengaruhi sikap pelamar sedemikian rupa terlepas mereka diangkat atau tidak dalam organisasi tesebut. Hasibuan (2013:174) menyatakan bah-wa rekrutmen merupakan usaha mencari dan mempengaruhi tenaga kerja, agar mau melamar lowongan pekerjaan yang ada dalam organisasi. Sedangkan pengertian rekrutmen menurut Sikula dalam Mangkunegara (2011:33) menjelaskan bah-wa "Recruitment including is the act or process of an organization attemting to obtain additional manpower for operational purpose. Recruiting involves acquiring further human resources to serve as instritusional input". Penarikan pegawai adalah tindakan atau proses dari suatu usaha organisasi untuk mendapatkan tambahan sumber daya manusia untuk tujuan operasional. Perekrutan karyawan melibatkan sumber daya manusia yang mampu berfungsi seba-gai input lembaga atau organisasi. Aktifitas rekrutmen dimulai pada saat calon mulai dicari, dan berakhir pada saat lamaran mereka diserahkan. Hal ini memerlukan keahlian bagi manajer organisasi untuk lebih jeli dan teliti dalam mengamati tahap demi tahap rekrutmen untuk mendapatkan calon pega-wai yang memenuhi kualifikasi yang telah ditentukan oleh organisasi tersebut guna membantu mencapai tujuan organisasi yang telah ditentukan jauh sebelumnya.

Lumban Gaol

menjelaskan bahwa rekrutmen adalah serangkaian kegia-tan yang dimulai ketika suatu perusahaan atau organisasi memerlukan tenaga kerja dan membuka lowongan sampai mendapatkan calon karyawan yang diinginkan/qualified sesuai dengan jabatan atau lowongan yang ada. Rekrutmen pada hakikatnya merupakan proses menentukan dan menarik pelamar atau kandidat yang mampu untuk bekerja dalam suatu perusahaan. Proses ini dimulai ketika para pelamar dicari dan berakhir ketika lamaran-lamaran mereka diserahkan.

Sumber-sumber rekrutmen tenaga kerja dapat dilakukan dengan dua cara yaitu internal (job posting, referensi manajemen, serikat buruh) dan eksternal (iklan, surat kabar, agen tenaga kerja pemerintah, swasta, lembaga pendidikan, nepotisme, perekutran elektronik dan lain-lain.

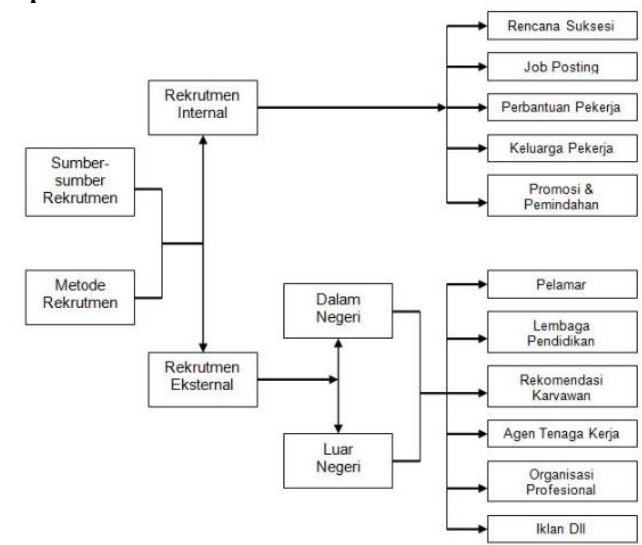

Sumber: Lumban Gaol (2014:375)

Gambar 2.1

Sumber dan Metode Rekrutmen 
Menurut Siagian (2015:102), rekrut-men adalah proses mencari, menemukan, dan menarik para pelamar yang kapabel untuk dipekerjakan dalam dan oleh suatu organisasi. Sementara indikator kinerja menurut Siagian yaitu :

a. Mencari, dalam melaksanakan tugas rekrutmen para pencari tenaga kerja mendasarkan kegiatannya pada peren-canaan sumber daya manusia yang telah ditentukan sebelumnya. Perlu ditekankan bahwa kegiatan rekrutmen tidak bisa tidak harus didasarkan pada perencanaan sumber daya manusia karena dalam rencana tersebut telah ditetapkan berbagai persyaratan yang harus dipenuhi oleh orang-orang yang ingin bekerja dalam organisasi yang bersangkutan.

b. Menemukan, jika para pencari tenaga kerja dapat memahami dan menentukan secara tepat metode rekrutmen yang akan digunakan, maka hasilnya adalah terjaringnya sekelompok pelamar yang dianggap paling memenuhi berbagai persyaratan untuk mengisi berbagai lo-wongan yang terdapat dalam organisasi.

c. Menarik, setelah proses mencari dan menemukan tenaga kerja sudah dilakukan oleh para pencari tenaga kerja maka proses yang terakhir yaitu menarik tenaga kerja yang sesuai dengan kualifikasi dan kapabel untuk bergabung dengan organisasi.

\section{B. Pengertian Kompensasi}

Kompensasi (balas jasa) adalah se-gala sesuatu yang diterima seseorang dalam bentuk fisik ataupun non fisik dan harus dihitung yang umumnya merupakan objek yang dikecualikan dari pajak penda-patan.
Tujuan pemberian kompensasi ini yaitu untuk memberikan rangsangan dan motivasi pada tenaga kerja untuk mening-katkan prestasi kerja dan efisiensi serta efektivitas produksi.

Menurut Hasibuan (2017:118) kom-pensasi adalah semua pendapatan yang berbentuk uang, barang langsung atau tidak langsung yang diterima karyawan sebagai imbalan atas jasa yang diberikan kepada perusahaan.

Menurut Veithzal Rivai (2014:357), Kompensasi adalah sesuatu yang diterima karyawan sebagai pengganti kontribusi jasa mereka pada perusahaan. Sedangkan Sedarmayanti (2017:239) mengungkapkan, kompensasi adalah segala sesuatu yang di terima oleh karyawan sebagai balas jasa kerja mereka.

Dengan demikian maka dapat dikata-kan bahwa kompensasi sebagai penghar-gaan atas penyerahan dan pemberian hasil kerja atau performance karyawan kepada organisasinya, maka organisasi memberikan balas jasa, imbalan jasa, penghargaan dan penghasilan. Kadarisman (2016:3) mengung-kapkan pentingnya kompensasi bagi karya-wan sangat berpengaruh terhadap perilaku dan kinerjanya.

\section{Pengertian Kinerja}

Wirawan (2012:5) menjelaskan bahwa konsep kinerja merupakan singkatan dari kinetika energi kerja yang padanannya dalam bahasa Inggris adalah performance. Istilah performance sering diiIndonesiakan sebagai performa. Kinerja adalah keluaran yang dihasilkan oleh fungsifungsi atau indikator-indikator suatu pekerjaan atau suatu profesi dalam waktu tertentu.

Cherington dalam Umam (2013:188) mengatakan bahwa kinerja 
menunjukkan pencapaian target kerja yang berkaitan de-ngan kualitas, kuantitas dan waktu. Menurut Rivai, dkk. (2013 : 548-549), kinerja merupakan perilaku nyata yang ditampilkan setiap orang sebagai prestasi kerja yang dihasilkan oleh karyawan sesuai dengan peranannya dalam perusahaan. Kinerja kar-yawan (prestasi kerja) adalah hasil kerja secara kualitas dan kuantitas yang dicapai oleh seorang karyawan dalam melaksanakan tugasnya sesuai dengan tanggung jawab yang diberikan kepadanya (Mangkunegara, 2013:67).

Menurut Wibowo (2013:349), kompen-sasi merupakan kontra prestasi terhadap penggunaan tenaga kerja atau jasa yang telah diberikan oleh tenaga kerja. Di dalam kompensasi terdapat sistem insentif yang menghubungkan kompensasi dengan kinerja. Dengan kompensasi kepada pekerja dibe-rikan penghargaan berdasarkan kinerja dan bukan berdasarkan senioritas atau jumlah jam kerja.

\section{METODE PENELITIAN}

Penelitian kuantittaif ini dilaksanakan pa-da PT. Sinergi Inti Pelangi yang beralamat di Jl. H. Noor No. 11, Pejaten Barat, Ps. Minggu Jakarta Selatan, Indonesia.

Penelitian menggunakan metode survei dengan mengumpulkan data melalui observasi dan penyebaran kuesioner kepada semua karyawan, yang hasilnya kemudian diolah melalui program SPSS Versi 23 tahun 2016, untuk mengetahui pengaruh antara variabel rekrutmen dan kompensasi terhadap kinerja karyawan PT Sinergi Inti Pelangi. Variabel yang akan diteliti adalah rekrutmen $\left(\mathrm{X}_{1}\right)$, kompensasi $\left(\mathrm{X}_{2}\right)$, dan kinerja (Y).
Populasi dalam penelitian ini adalah keseluruhan subyek penelitian yang dijadikan sasaran. Populasi ini meliputi karyawan yang berjumlah 50 orang.Sampel dalam penelitian ini adalah sampel jenuh yang artinya semua populasi.

Data yang diperoleh dari penelitian harus dianalisis terlebih dahulu dengan uji validitas dan realibiltas untuk mengetahui apakah butir-butir pernyataan yang ada sudah memenuhi batas alfa $(\alpha)$. Kemudian dilakukan uji asumsi klasik dengan uji normalitas, homogenitas, autokorelasi, multi-kolinieritas, dan heterokedastisitas.Uji regresi linier sederhana dan berganda serta koefisien determinasi.

Terakhir dilakukan pengujian hipotesis penelitian untuk melihat seberapa besar pengaruh variabel $\mathrm{X}_{1}$ dan $\mathrm{X}_{2}$ terhadap $\mathrm{Y}$, dengan Uji Parsial t-test dan Uji Simultan F-test.

\section{HASIL DAN PEMBAHASAN}

Berdasarkan data yang diperoleh dari HRD PT. Sinergi Inti Pelang, maka hasil analisis data dengan melihat karakteristik responden-nya yang berjumlah 50 orang dapat disim-pulkan hal-hal sebagai berikut:

1. Hasil distribusi frekuensi 50 responden menurut jenis kelamin didapatkan data jumlah karyawan 50 orang dengan laki-laki 18 orang $((36 \%)$ dan perempuan 32 orang (64\%).

2. Hasil distribusi frekuensi 50 responden menurut usia diperoleh bahwa sebagian besar responden berada dalam rentang usia 19-34 tahun yaitu sebanyak 30 orang $(60 \%)$, sedangkan yang berada dalam rentang usia 35-50 tahun se-banyak 19 orang (38\%), dan yang berada dalam rentang usia $>50$ tahun sebanyak 1 orang (2\%).

3. Hasil distribusi frekuensi 50 responden menurut tingkat pendidikan diperoleh 
bahwa sebagian besar responden berada dalam tingkat pendidikan SMA/SMK yaitu sebanyak 28 orang (56\%), dalam tingkat pendidikan D3 yaitu sebanyak 5 orang (10\%), dalam tingkat pendidikan S1 se-banyak 15 orang $(30 \%)$, dan dalam tingkat pendidikan S2 sebanyak 2 orang (4\%).

4. Hasil distribusi frekuensi 50 responden menurut masa kerja diperoleh sebagian besar responden yang berada dalam rentang kerja 1-5 tahun sebanyak 27 orang $(54 \%)$, responden yang berada dalam rentang kerja 6-10 tahun sebanyak 9 orang (18\%), responden yang berada dalam rentang kerja 11-15 tahun se-banyak 11 orang (22\%), dan responden yang berada dalam rentang kerja $>15$ tahun sebanyak 3 orang $(6 \%)$.

\section{A. Uji Validitas}

Uji Validitas digunakan untuk menguji pertanyaan maupun pernyataan pada kue-sioner yang disebar apakah valid atau tidak. Hasil uji validitas menggunakan program SPSS 23 dengan membandingkan nilai Pearson Correlation (Korelasi Product Moment) dengan $r$ tabel dengan mengguna-kan tingkat keyakinan $95 \%$, $\alpha=5 \%$ dan $\mathrm{n}=50$, diperoleh hasil untuk $r$ tabel sebesar 0, 278. Untuk lebih jelasnya, hasil uji validitas dapat dilihat pada tabel dibawah ini

\section{Tabel 4.1}

\section{Hasil Uji Validitas Rekrutmen (X1)}

\begin{tabular}{|c|c|c|c|c|}
\hline Indikator & Pernyataan & Nilai r hitung & Nilai r tabel & Keterangan \\
\hline \multirow{3}{*}{ Mencari } & Pernyataan 1 & 0,6 & 0,278 & Valid \\
\cline { 2 - 5 } & Pernyataan 2 & 0,662 & 0,278 & Valid \\
\cline { 2 - 5 } & Pernyataan 3 & 0,315 & 0,278 & Valid \\
\hline \multirow{3}{*}{ Menemukan } & Pernyataan 4 & 0,619 & 0,278 & Valid \\
\cline { 2 - 5 } & Pernyataan 5 & 0,677 & 0,278 & Valid \\
\cline { 2 - 5 } & Pernyataan 6 & 0,767 & 0,278 & Valid \\
\hline \multirow{4}{*}{ Menarik } & Pernyataan 7 & 0,583 & 0,278 & Valid \\
\cline { 2 - 5 } & Pernyataan 8 & 0,721 & 0,278 & Valid \\
\cline { 2 - 5 } & Pernyataan 9 & 0,473 & 0,278 & Valid \\
\cline { 2 - 5 } & Pernyataan 10 & 0,677 & 0,278 & Valid \\
\hline
\end{tabular}

Sumber: Hasil Olahan Data SPSS 23

\section{Tabel 4.2}

Hasil Uji Validitas Kompensasi (X2)

\begin{tabular}{|l|l|c|c|c|}
\hline Indikator & Pernyataan & Nilai $\mathbf{r}$ hitung & Nilai r tabel & Keterangan \\
\hline \multirow{2}{*}{ Gaji } & Pernyataan 1 & 0,29 & 0,278 & Valid \\
\cline { 2 - 5 } & Pernyataan 2 & 0,283 & 0,278 & Valid \\
\hline \multirow{2}{*}{ Upah } & Pernyataan 3 & 0,289 & 0,278 & Valid \\
\cline { 2 - 5 } & Pernyataan 4 & 0,847 & 0,278 & Valid \\
\hline \multirow{2}{*}{$\begin{array}{l}\text { Upah } \\
\text { Insentif }\end{array}$} & Pernyataan 5 & 0,699 & 0,278 & Valid \\
\cline { 2 - 5 } & Pernyataan 6 & 0,801 & 0,278 & Valid \\
\cline { 2 - 5 } & Pernyataan 7 & 0,5 & 0,278 & Valid \\
\hline \multirow{2}{*}{$\begin{array}{l}\text { Benefit and } \\
\text { Service }\end{array}$} & Pernyataan 8 & 0,721 & 0,278 & Valid \\
\cline { 2 - 5 } & Pernyataan 9 & 0,621 & 0,278 & Valid \\
\cline { 2 - 5 } & Pernyataan 10 & 0,801 & 0,278 & Valid \\
\hline
\end{tabular}

Sumber: Hasil Olahan Data SPSS 23

Tabel 4.3

Hasil Uji Validitas Kinerja Karyawan (Y)

\begin{tabular}{|l|c|c|c|c|}
\hline Indikator & Pernyataan & Nilai $\mathbf{r}$ hitung & Nilai $\mathbf{r}$ tabel & Keterangan \\
\hline \multirow{2}{*}{$\begin{array}{l}\text { Kualitas } \\
\text { Kerja }\end{array}$} & Pernyataan 1 & 0,587 & 0,278 & Valid \\
\cline { 2 - 5 } & Pernyataan 2 & 0,879 & 0,278 & Valid \\
\hline \multirow{2}{*}{$\begin{array}{l}\text { Kuantitas } \\
\text { Kerja }\end{array}$} & Pernyataan 3 & 0,632 & 0,278 & Valid \\
\cline { 2 - 5 } & Pernyataan 4 & 0,845 & 0,278 & Valid \\
\hline \multirow{2}{*}{$\begin{array}{l}\text { Pelaksanaan } \\
\text { Tugas }\end{array}$} & Pernyataan 5 & 0,565 & 0,278 & Valid \\
\cline { 2 - 5 } & Pernyataan 6 & 0,798 & 0,278 & Valid \\
\cline { 2 - 5 } & Pernyataan 7 & 0,632 & 0,278 & Valid \\
\hline \multirow{2}{*}{$\begin{array}{l}\text { Tanggung } \\
\text { Jawab }\end{array}$} & Pernyataan 8 & 0,69 & 0,278 & Valid \\
\cline { 2 - 5 } & Pernyataan 9 & 0,788 & 0,278 & Valid \\
\cline { 2 - 5 } & Pernyataan 10 & 0,879 & 0,278 & Valid \\
\hline
\end{tabular}

Sumber: Hasil Olahan Data SPSS 23

\section{B. Uji Reliabilitas}

Butir pertanyaan dalam variabel dikatakan reliabel atau terpercaya apabila jawaban responden adalah konsisten atau stabil dari waktu ke waktu. Suatu konstruk atau variabel dikatakan reliabel jika memberikan nilai Cronbach's Alpha $\geq 0,60$.

Tabel 4.4

Hasil Uji Reliabilitas

\begin{tabular}{|l|c|c|c|}
\hline \multicolumn{1}{|c|}{ Variabel } & Nilai Alpha & Kriteria & Keputusan \\
\hline Rekrutmen $\left(\mathrm{X}_{1}\right)$ & 0,803 & $>0,60$ & Reliabel \\
\hline Kompensasi $\left(\mathrm{X}_{2}\right)$ & 0,787 & $>0,60$ & Reliabel \\
\hline Kinerja Karyawan $(\mathrm{Y})$ & 0,903 & $>0,60$ & Reliabel \\
\hline
\end{tabular}

Sumber: Hasil Olahan Data SPSS 23

Berdasarkan tabel diatas dapat diketahui bahwa masing-masing variabel antara variabel Rekrutmen $\left(\mathrm{X}_{1}\right)$, Kompensasi $\left(\mathrm{X}_{2}\right)$ dan Kinerja Karyawan (Y), ternyata diperoleh nilai Cronbach Alpha $\geq 0,60$. Dengan demikian maka hasil uji reabilitas 
terhadap keseluruhan variabel adalah reliabel.

C. Uji Asumsi Klasik

1. Uji Normalitas

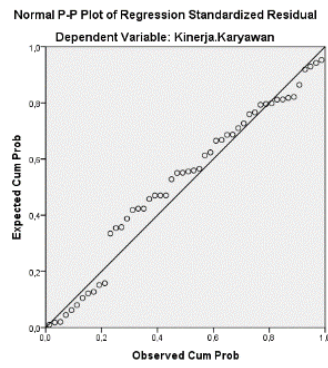

Sumber: Hasil Olahan Data SPSS 23

Gambar 4.1

Uji Normalitas Data P-P Plot

Melihat tampilan grafik normal probabilty plot diatas, dapat disimpulkan bahwa pada grafik normal probability plot terlihat titiktitik menyebar di sekitar garis diagonal, sehingga dapat disimpulkan bah-wa data yang digunakan dalam penelitian ini berdistribusi normal.

\section{Uji Multikolinieritas}

\section{Tabel 4.5}

\section{Hasil Uji Multikolinearitas}

\begin{tabular}{|c|l|c|c|c|c|}
\hline \multirow{2}{*}{ Model } & \multicolumn{4}{|c|}{ Collinearity Statistics } \\
\cline { 3 - 6 } & Tolerance & Kriteria & VIF & Kriteria \\
\hline \multirow{3}{*}{1} & Constant) & & & & \\
\cline { 2 - 6 } & Rekrutmen & 0,664 & $>0,1$ & 1,505 & $<10$ \\
\cline { 2 - 6 } & Kompensasi & 0,664 & $>0,1$ & 1,505 & $<10$ \\
\hline
\end{tabular}

Sumber: Hasil Olahan Data SPSS 23

Berdasarkan hasil tersebut maka dalam model regresi tidak terjadi multikolinea-ritas atau korelasi yang sempurna antara variabel-variabel bebas, yaitu Rekrutmen dan Kompensasi, karena nilai VIF lebih kecil dari 10 dan nilai tolerance lebih besar dari 0,1 .

\section{Uji Heteroskedastisitas}

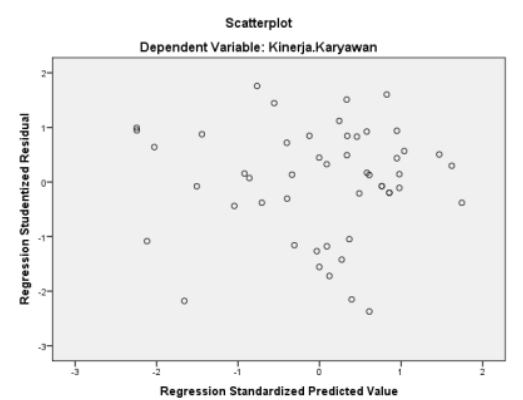

Sumber: Hasil Olahan Data SPSS 23

Gambar 4.2

Uji Heterokedastisitas

Berdasarkan output Scatterplots di atas diketahui bahwa:

a. Titik-titik data penyebar di atas dan di bawah atau di sekitar angka 0 .

b. Titik-titik tidak mengumpul hanya di atas atau di bawah saja.

c. Penyebaran titik-titik data tidak berpola.

Dengan demikian dapat disimpulkan bah-wa tidak terjadi masalah heteros-kedastisitas, hingga model regresi yang baik dan ideal sudah terpenuhi.

\section{Analisis Data}

\section{Analisis Deskriptif}

a. Analisis Deskriptif Rekrutmen $\left(\mathrm{X}_{1}\right)$ Berdasarkan data yang terkumpul dari kuesioner tentang variabel rekrutmen $\left(\mathrm{X}_{1}\right)$, bahwa jawaban tidak setuju dan sangat tidak setuju skor tertinggi $34 \%$ adalah pernyataan no. 9 yaitu "HRD memilih kandidat yang sesuai dengan hasil tes kesehatan (medical check up) yang sudah ditentukan oleh peru-sahaan". Hal ini menunjukkan bahwa sebagian besar responden tidak setuju dan sangat tidak setuju dengan pernyataan tersebut, yang berarti sebagian besar responden menilai bahwa pemilihan kandidat tidak hanya di pilih 
berdasarkan de-ngan tes kesehatan (medical check up) saja

b. Analisis Deskriptif Kompensasi $\left(\mathrm{X}_{2}\right)$

Berdasarkan data yang terkumpul dari kuesioner tentang variabel kompensasi $\left(\mathrm{X}_{2}\right)$, bahwa jawaban tidak setuju dan sangat tidak setuju skor tertinggi $34 \%$ adalah pernyataan no. 2 yaitu "Besar-nya gaji yang saya terima sudah sesuai dengan UMP". Hal ini menunjukkan bahwa sebagian besar respon-den tidak setuju dan sangat tidak setuju dengan pernyataan tersebut, yang berarti sebagian besar respon-den menilai bahwa gaji yang diterima oleh karyawan belum memenuhi stan-dar atau sesuai dengan Upah Mini-mum Provinsi (UMP).

c. Analisis Deskriptif Kinerja (Y)

Berdasarkan data yang terkumpul dari kuesioner tentang variabel kinerja (Y), bahwa bahwa jawaban tidak setuju dan sangat tidak setuju skor tertinggi $40 \%$ adalah pernyataan no. 4 yaitu "Saya bersedia lembur apabila peker-jaan saya belum selesai". Hal ini menunjukkan bahwa sebagian besar responden kurang setuju dan tidak setuju dengan pernyataan tersebut, yang berarti sebagian besar responden tidak bersedia lembur apabila pekerjaannya belum selesai.

\section{Analisis Verifikatif}

a. Uji Regresi Linier Sederhana

Analisis regresi linier sederhana digu-nakan untuk mengukur besarnya pengaruh variabel bebas terhadap variabel terikat dan memprediksi varia-bel terikat dengan menggunakan va-riabel bebas.
Tabel 4.6

\section{Regresi Sederhana Rekrutmen} Terhadap Kinerja

\begin{tabular}{|c|c|c|c|c|c|c|}
\hline & \multirow{2}{*}{ Model } & \multicolumn{2}{|c|}{$\begin{array}{c}\text { Unstandardized } \\
\text { Coefficients } \\
\end{array}$} & \multirow{2}{*}{\begin{tabular}{|c|}
$\begin{array}{c}\text { Standardized } \\
\text { Coefficients }\end{array}$ \\
Beta \\
\end{tabular}} & \multirow{2}{*}{$t$} & \multirow{2}{*}{ Sig. } \\
\hline & & B & $\begin{array}{l}\text { Std. } \\
\text { Error }\end{array}$ & & & \\
\hline \multirow{2}{*}{1} & (Constant) & 1,824 & 5,601 & & 0,326 & 0,746 \\
\hline & Rekrutmen & 0,913 & 0,147 & 0,667 & 6,197 & 0 \\
\hline
\end{tabular}

Sumber: Hasil Olahan Data SPSS 23

Berdasarkan hasil perhitungan ter-sebut maka dapat diperoleh persa-maan regresi linier sederhana seba-gai berikut :

$\mathrm{Y}=1,824+0,913 \mathrm{X}$

1) Nilai (a) atau konstanta sebesar 1,824 nilai ini menunjukan bahwa pada saat rekrutmen $\left(\mathrm{X}_{1}\right)$ tidak meningkat, maka kinerja karyawan (Y) akan tetap bernilai 1,824 .

2) Nilai regresi (b) sebesar 0,913 (positif) yaitu menunjukkan hubungan yang searah yang artinya setiap rekrutmen ditingkatkan sebe-ar satu satuan maka akan mening-katkan kinerja karyawan sebesar 0,913 satuan.

\section{Tabel 4.7}

\section{Regresi Sederhana Kompensasi} Terhadap Kinerja

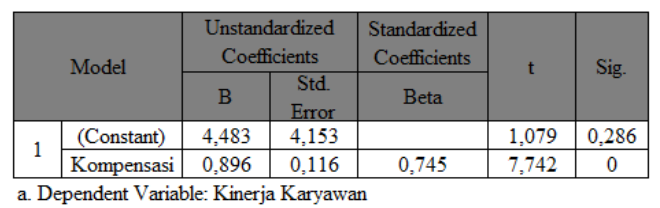

Sumber: Hasil Olahan Data SPSS 23

Berdasarkan hasil perhitungan ter-sebut maka dapat diperoleh persa-maan regresi linier sederhana sebagai berikut :

$$
\mathrm{Y}=4,483+0,896 \mathrm{X}
$$

1) Nilai (a) atau konstanta sebesar 4,483 nilai ini menunjukan bahwa pada saat kompensasi (X2) tidak meningkat, maka kinerja karyawan (Y) akan tetap bernilai 4,483 . 
2) Nilai regresi (b) sebesar 0,896 (positif) yaitu menunjukkan hubungan yang searah yang artinya setiap kompensasi ditingkatkan sebesar satu satuan maka akan meningkatkan kinerja karyawan sebesar 0,896 satuan.

b. Uji Regresi Linier Berganda

Analisis regresi berganda digunakan untuk mengetahui seberapa besar pengaruh variabel bebas (Indepen-dent) yaitu: Rekrutmen $\left(\mathrm{X}_{1}\right)$, dan Kompensasi (X2) terhadap variabel terikat (Dependent) kinerja karyawan (Y). Dengan dibantu program SPSS 23 dalam perhitungannya dapat diperoleh hasil sebagai berikut:

Tabel 4.8

Regresi Berganda Kompensasi dan Rekrutmen Terhadap Kinerja

\begin{tabular}{|l|l|c|c|c|c|r|}
\hline \multicolumn{2}{|c|}{ Coefficients $^{2}$} \\
\hline \multirow{2}{*}{ Model } & $\begin{array}{c}\text { Unstandardized } \\
\text { Coefficients }\end{array}$ & $\begin{array}{c}\text { Standardized } \\
\text { Coefficients }\end{array}$ & \multirow{2}{*}{$\mathrm{t}$} & \multirow{2}{*}{ Sig. } \\
\cline { 2 - 5 } & B & $\begin{array}{c}\text { Std. } \\
\text { Error }\end{array}$ & Beta & & \\
\hline \multirow{2}{*}{1} & (Constant) & $-5,05$ & 4,768 & & $-1,059$ & 0,295 \\
\cline { 2 - 5 } & Rekrutmen & 0,484 & 0,147 & 0,354 & 3,287 & 0,002 \\
\hline & Kompensasi & 0,649 & 0,129 & 0,54 & 5,021 & 0 \\
\hline
\end{tabular}

Sumber: Hasil Olahan Data SPSS 23

Berdasarkan hasil perhitungan terse-but maka dapat diperoleh persamaan regresi linier berganda sebagai berikut:

$\mathrm{Y}=-5,050+0,484 \mathrm{X} 1+0,649 \mathrm{X} 2$

Dimana

$$
\begin{aligned}
& \mathrm{X} 1=\text { Rekrutmen } \\
& \mathrm{X} 2=\text { Kompensasi } \\
& \mathrm{Y}=\text { Kinerja Karyawan }
\end{aligned}
$$

1) Nilai konstanta sebesar 5,050 artinya apabila variabel rekrutmen (X1) dan kompensasi (X2) dalam keadaan konstan, maka kinerja kar-yawan (Y) adalah sebesar 5,050 .

2) Nilai regresi $0,484 X 1$ artinya apabila variabel rekrutmen (X1) meningkat 1 satuan dan variabel kompensasi (X2) tetap, maka kinerja karyawan (Y) akan meningkat sebesar 0,484 satuan.

3) Nilai regresi $0,649 \times 2$ artinya apabila variabel kompensasi (X2) meningkat 1 satuan, dan variabel rekrutmen (X1) tetap, maka kinerja karyawan (Y) akan meningkat sebesar 0,649 satuan.

c. Koefisien Korelasi

Analisis koefisien korelasi digunakan untuk mengetahui kekuatan hubungan antara variabel independen terhadap variabel dependen. Untuk mengetahui bagaimana kekuatan hubungan antar variabel dapat dilihat pada tabel 4.16 berikut ini :

\begin{tabular}{|c|c|c|c|c|}
\hline \multicolumn{5}{|c|}{ Correlations } \\
\hline & & Kompensasi & Rekrutmen & Kinerja \\
\hline \multirow{3}{*}{$\begin{array}{l}\text { Kompens } \\
\text { asi }\end{array}$} & $\begin{array}{l}\text { Pearson } \\
\text { Correlation }\end{array}$ & 1 & $.579^{* *}$ & $.667^{* * *}$ \\
\hline & Sig. (2-tailed) & & 0 & 0 \\
\hline & $\mathrm{N}$ & 50 & 50 & 50 \\
\hline \multirow{3}{*}{$\begin{array}{l}\text { Rekrutme } \\
\text { n }\end{array}$} & \begin{tabular}{|l|} 
Pearson \\
Correlation \\
\end{tabular} & $579^{* *}$ & 1 & $.745^{* *}$ \\
\hline & Sig. (2-tailed) & 0 & & 0 \\
\hline & $\mathrm{N}$ & 50 & 50 & 50 \\
\hline \multirow{3}{*}{ Kinerja } & \begin{tabular}{|l|} 
Pearson \\
Correlation
\end{tabular} &, $667^{* *}$ &, $745^{* *}$ & 1 \\
\hline & \begin{tabular}{|l|} 
Sig. (2-tailed) \\
\end{tabular} & 0 & 0 & \\
\hline & $\mathrm{N}$ & 50 & 50 & 50 \\
\hline
\end{tabular}

Tabel 4.9

\section{Koefisien Korelasi}

Berdasarkan nilai korelasi yang didapat maka dapat diketahui bahwa :

1) Nilai korelasi rekrutmen (X1) sebesar 0,667 yang berarti bahwa hubungan antara rekrutmen (X1) terhadap kinerja karyawan (Y) pada PT. Sinergi Inti Pelangi memiliki tingkat hubungan yang kuat.

2) Nilai korelasi kompensasi (X2) sebesar 0,745 yang berarti bahwa hubungan antara kompensasi (X2) terhadap kinerja karyawan (Y) pada PT. Sinergi Inti Pelangi memiliki tingkat hubungan yang kuat.

3) 


\section{Pengujian Hipotesis}

a. Uji Siginifikan Parsial (Uji T)

Pengujian $t$ hitung digunakan untuk me-ngetahui kualitas keberartian regresi anta-ra tiap-tiap variabel bebas $(\mathrm{X})$ ter-dapat pengaruh atau tidak terhadap variabel terikat (Y).

\section{Tabel 4.10}

Hasil Uji Signifikan Parsial (Uji T)

\begin{tabular}{|c|c|c|c|c|c|c|}
\hline \multicolumn{7}{|c|}{ Coefficients ${ }^{\mathrm{a}}$} \\
\hline & \multirow{2}{*}{ Model } & \multicolumn{2}{|c|}{$\begin{array}{l}\text { Unstandardized } \\
\text { Coefficients }\end{array}$} & \multirow{2}{*}{$\begin{array}{c}\text { Standardized } \\
\text { Coefficients } \\
\text { Beta }\end{array}$} & \multirow{2}{*}{$\mathrm{t}$} & \multirow{2}{*}{ Sig. } \\
\hline & & B & $\begin{array}{l}\text { Std. } \\
\text { Error }\end{array}$ & & & \\
\hline \multirow{3}{*}{1} & (Constant) & $-5,05$ & 4,768 & & $-1,059$ & 0,295 \\
\hline & Rekrutmen & 0,484 & 0,147 & 0,354 & 3,287 & 0,002 \\
\hline & Kompensasi & 0,649 & 0,129 & 0,54 & 5,021 & 0 \\
\hline
\end{tabular}

Sumber: Hasil Olahan Data SPSS 23

Dari tabel di atas diperoleh $\mathrm{t}$ hitung untuk variabel rekrutmen (X1) lebih besar dari t tabel, yakni $3,287>2,011$ dan nilai sig-nifikansi $0,02<\alpha 0,05, \quad$ jadi variabel rekrutmen mempunyai pengaruh yang positif dan signifikan terhadap kinerja karyawan (Y) secara parsial.

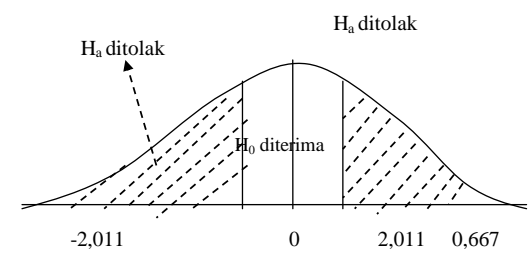

Sumber: Hasil Olahan Data SPSS 23

Gambar 4.3

Kriteria Penolakan dan Penerimaan Hipotesis X1

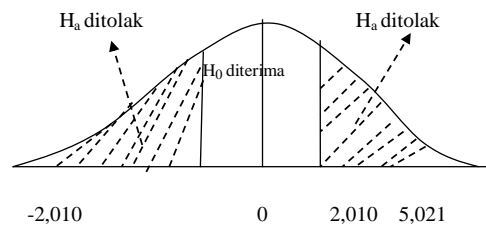

Gambar 4.4

Kriteria Penolakan dan Penerimaan Hipotesis X2
Dari hasil uji tersebut di atas dapat di-simpulkan bahwa variabel yang paling dominan pengaruhnya terhadap kinerja karyawan pada PT. Sinergi Inti Pelangi adalah variabel Kompensasi dengan $t$ hitung sebesar 5,021 dan nilai signifikansi terkecil $(0,000)$.

b. Uji Siginifikan Simultan (Uji F)

Dalam melakukan uji F hitung parameter yang digunakan adalah dengan mem-bandingkan $\mathrm{F}$ hitung > F tabel. Pengujian terhadap pengaruh variabel bebas terha-dap variabel terikat secara simultan dilakukan dengan uji $\mathrm{F}$ dengan hasil yang dapat dilihat pada tabel berikut ini:

Tabel 4.11

Hasil Uji Signifikan Simultan (Uji F)

\begin{tabular}{|c|l|c|c|c|c|c|}
\hline \multicolumn{2}{|c|}{ ANOVA $^{\mathrm{a}}$} \\
\hline \multirow{2}{*}{1} & $\begin{array}{c}\text { Sum of } \\
\text { Squares }\end{array}$ & df & Mean Square & F & Sig. \\
\hline \multirow{7}{*}{1} & Regression & 1367,24 & 2 & 683,618 & 41,491 &, $000^{\mathrm{b}}$ \\
\cline { 2 - 7 } & Residual & 774,384 & 47 & 16,476 & & \\
\cline { 2 - 6 } & Total & 2141,62 & 49 & & & \\
\hline \\
a. Dependent Variable: Kinerja. Karyawan \\
b. Predictors: (Constant), Kompensasi, Rekrutmen
\end{tabular}

Sumber : Hasil Olahan Data SPSS 23

Berdasarkan tabel diatas menunjukkan hasil perhitungan diperoleh nilai $\mathrm{F}$ hitung sebesar 41,491 dengan tingkat signifikan-si sebesar $0,000<0,05$. Sementara nilai $F$ tabel sebesar 3,20 (dari perhitungan $\mathrm{dk} 1=2=0,05 \mathrm{dan} \mathrm{dk}=$ 50-2-1 = 47 diperoleh $\mathrm{F}$ tabel 3,20). Ini berarti bahwa nilai $F$ hitung 41,491 > F tabel 3,20 dengan siginifikan $0,000<0,05$ dengan demikian $\mathrm{Ho}$ ditolak dan $\mathrm{Ha}$ diterima, artinya bahwa rekrutmen $\left(\mathrm{X}_{1}\right)$ dan kompensasi $\left(\mathrm{X}_{2}\right)$ berpengaruh secara simultan atau bersama-sama dan signifi-kan terhadap kinerja karyawan pada PT. Sinergi Inti Pelangi. 
c. Koefisien Determinasi $\left(\mathrm{R}^{2}\right)$ Koefisien determinasi $\left(\mathrm{R}^{2}\right)$ digunakan untuk mengetahui seberapa besar kontribusi variabelvariabel bebas dalam menjelaskan variabel-variabel terikat dengan hasil yang dapat dilihat pada tabel dibawah ini:

Tabel 4.12

Koefisien Determinasi Rekrutmen Terhadap Kinerja

\begin{tabular}{|c|c|c|c|c|}
\hline \multicolumn{5}{|c|}{ Model Summary } \\
\hline Model & R & R Square & $\begin{array}{l}\text { Adjusted } \\
\text { R Square }\end{array}$ & $\begin{array}{c}\text { Std. Error of } \\
\text { the Estimate }\end{array}$ \\
\hline 1 &, $667^{\mathbf{2}}$ & 0,444 & 0,433 & 4,979 \\
\hline
\end{tabular}

a. Predictors: (Constant), Rekrutmen

b. Dependent Variable: Kinerja.Karyawan

Sumber : Hasil Olahan Data SPSS 23

Berdasarkan tabel di atas, dapat diketahui bahwa besarnya nilai koefisien determi-nasi ditunjukkan oleh nilai $\mathrm{R}$ Square yaitu sebesar 0,444 yang artinya bahwa re-krutmen (X1) memberikan kontribusi ter-hadap variabel kinerja karyawan (Y) sebesar $44,4 \%$, sedangkan sisanya sebe-sar $55,6 \%$ di pengaruhi oleh variabel lain yang tidak diteliti dalam penelitian ini.

Tabel 4.13

Koefisien Determinasi Kompensasi Terhadap Kinerja

\begin{tabular}{|c|c|c|c|c|}
\hline \multicolumn{5}{|c|}{ Model Summary } \\
\hline Model & R & R Square & $\begin{array}{l}\text { Adjusted } \\
\text { R Square }\end{array}$ & $\begin{array}{c}\text { Std. Error of } \\
\text { the Estimate }\end{array}$ \\
\hline 1 &, $745^{\mathbf{a}}$ & 0,555 & 0,546 & 4,454 \\
\hline
\end{tabular}

a. Predictors: (Constant), Kompensasi

b. Dependent Variable: Kinerja.Karyawan

Sumber : Hasil Olahan Data SPSS 23

Berdasarkan tabel di atas, dapat diketahui bahwa besarnya nilai koefisien determi-nasi ditunjukkan oleh nilai $R$ Square yaitu sebesar 0,555 yang artinya bahwa Kompensasi

$\left(\mathrm{X}_{2}\right)$ memberikan kontribusi terhadap variabel kinerja karyawan (Y) sebesar $55,5 \%$, sedangkan sisanya sebe-sar $44,5 \%$ di pengaruhi oleh variabel lain yang tidak diteliti dalam penelitian ini.

\section{Tabel 4.14}

Koefisien Determinasi Rekrutmen dan Kompensasi Terhadap Kinerja

\begin{tabular}{|c|c|c|c|c|}
\hline \multicolumn{5}{|c|}{ Model Summary } \\
\hline Model & R & R Square & $\begin{array}{l}\text { Adjusted } \\
\text { R Square }\end{array}$ & $\begin{array}{c}\text { Std. Error of } \\
\text { the Estimate }\end{array}$ \\
\hline 1 &, $799^{2}$ & 0,638 & 0,623 & 4,059 \\
\hline
\end{tabular}

a. Predictors: (Constant), Kompensasi, Rekrutmen

Sumber : Hasil Olahan Data SPSS 23

Berdasarkan tabel di atas, dapat diketahui bahwa besarnya nilai koefisien determi-nasi ditunjukkan oleh nilai $\mathrm{R}$ Square yaitu sebesar 0,638 yang artinya bahwa Rekrutmen $\left(\mathrm{X}_{1}\right)$ dan (Kompensasi $\left(\mathrm{X}_{2}\right)$ memberikan kontribusi terhadap variabel kinerja karyawan (Y) sebesar 63,8\%, sedangkan sisanya sebesar $36,2 \%$ di- pengaruhi oleh variabel lain yang tidak diteliti dalam penelitian ini.

\section{E. Pembahasan}

1. Pengaruh Rekrutmen Terhadap Kinerja Karyawan.

Berdasarkan hasil perhitungan ana-lisis regresi linier berganda diketahui bahwa variabel Rekrutmen $\left(\mathrm{X}_{1}\right)$ diperoleh koefisien sebesar 0,484 dan nilai signifikansi 0,649 yang berarti jika variabel rekrutmen meningkat 1 satuan maka akan meningkatkan kinerja karyawan PT. Sinergi Inti pelangi sebesar 0,484 satuan. Dengan kata lain kinerja karyawan akan meningkat sejalan dengan perbaikan rekrutmen pada PT. Sinergi Inti Pelangi. 
Berdasarkan hasil perhitungan uji t (uji parsial) diketahui bahwa nilai $t$ hitung untuk variabel rekrutmen $\left(\mathrm{X}_{1}\right)$ lebih besar dari $\mathrm{t}$ tabel yaitu 3,287>2,011 dan nilai signifikansinya $0,002<\alpha 0,05$, jadi varia-bel rekrutmen mempunyai pengaruh yang positif dan signifikan terhadap kinerja karyawan (Y) secara parsial pada PT. Sinergi Inti Pelangi.

Berdasarkan hasil nilai koefisien determinasi, besarnya nilai korelasi/ hubungan antara rekrutmen terhadap kinerja karyawan $(\mathrm{R})$ yaitu sebesar 0,667 dimana diperoleh koefisien determinasi $\left(\mathrm{R}^{2}\right)$ sebesar 0,444 yang berarti bahwa pengaruh variabel bebas rekrutmen ter-hadap variabel kinerja karyawan adalah sebesar $44,4 \%$.

2. Pengaruh Kompensasi Terhadap Kinerja Karyawan.

Berdasarkan hasil perhitungan anali-sis regresi linier berganda diketahui bahwa variabel Kompensasi $\quad\left(\mathrm{X}_{2}\right) \quad$ diperoleh koefisien sebesar 0,649 dan nilai signifikansi 0,000 yang berarti jika variabel kompensasi meningkat 1 satuan maka akan meningkatkan kinerja kar-yawan PT. Sinergi Inti pelangi sebesar 0,649 satuan. Dengan kata lain kinerja karyawan akan meningkat sejalan dengan perbaikan kompensasi pada PT. Sinergi Inti Pelangi.

Berdasarkan hasil perhitungan uji t (uji parsial) diketahui bahwa nilai $t$ hitung untuk variabel kompensasi $\left(\mathrm{X}_{2}\right)$ lebih besar dari $\mathrm{t}$ tabel yaitu 5,021>2,011 dan nilai signifikansinya $0,000<\alpha 0,05$, jadi variabel kompensasi mempunyai penga-ruh yang positif dan signifikan terhadap kinerja karyawan (Y) secara parsial pada PT. Sinergi Inti Pelangi.

Berdasarkan hasil nilai koefisien determinasi, besarnya nilai korelasi/ hubungan antara kompensasi terhadap kinerja karyawan (R) yaitu sebesar 0,745 dimana diperoleh koefisien determinasi $\left(\mathrm{R}^{2}\right)$ sebesar 0,555 yang berarti bahwa pengaruh variabel bebas rekrutmen terha-dap variabel kinerja karyawan adalah sebesar $55,5 \%$.

3. Pengaruh Rekrutmen dan Kompensasi Terhadap Kinerja Karyawan

Berdasarkan hasil perhitungan analisis regresi linier berganda diketahui bahwa variabel Rekrutmen $\left(\mathrm{X}_{1}\right)$ dan Kompensasi $\left(\mathrm{X}_{2}\right)$ diperoleh koefisien se-besar 0,649 dan nilai signifikansi 0,000 yang berarti jika variabel Rekrutmen $\left(\mathrm{X}_{1}\right)$ dan Kompensasi $\left(\mathrm{X}_{2}\right)$ meningkat 1 satuan maka akan meningkatkan kinerja kar-yawan PT. Sinergi Inti pelangi sebesar 0,649 satuan. Dengan kata lain kinerja karyawan akan meningkat sejalan dengan perbaikan rekrutmen dan kompensasi pada PT. Sinergi Inti Pelangi.

Berdasarkan hasil perhitungan uji $\mathrm{F}$ (uji simultan) diperoleh $\mathrm{F}$ hitung untuk variabel rekrutmen $\left(\mathrm{X}_{1}\right)$ dan kompensasi $\left(\mathrm{X}_{2}\right)$ lebih besar dari $\mathrm{F}$ tabel, yakni 41,490>3,20, jadi variabel rekrutmen $\left(\mathrm{X}_{1}\right)$ dan kompensasi $\left(\mathrm{X}_{2}\right)$ mempunyai penga-ruh yang positif dan signifikan terhadap kinerja karyawan (Y) secara simultan (bersama-sama).

Berdasarkan hasil nilai koefisien determinasi, besarnya nilai korelasi/ hubungan antara kompensasi terhadap kinerja 
karyawan (R) yaitu sebesar 0,799 dimana diperoleh koefisien determinasi $\left(\mathrm{R}^{2}\right)$ sebesar 0,638 yang berarti bahwa pengaruh variabel bebas rekrutmen terhadap variabel kinerja karyawan adalah sebesar $63,8 \%$.

\section{KESIMPULAN DAN SARAN}

\section{A. Kesimpulan}

Kesimpulan atas masalah penelitian di-dasarkan atas temuan permasalahan pene-litian yang teridentifikasi dan tersusun pada Bab I dimana tujuan dari penelitian ini adalah mencari jawaban atas rumusan masalah yang diajukan dalam penelitian ini.

Berdasarkan hasil penelitian dan pembahasan mengenai rekrutmen dan kom-pensasi terhadap kinerja karyawan pada PT. Sinergi Inti Pelangi dapat disimpulkan bahwa:

1. Besarnya nilai korelasi/hubungan antara rekrutmen terhadap kinerja karyawan (R) yaitu sebesar 0,667 dimana diperoleh koefisien determinasi $\left(\mathrm{R}^{2}\right)$ sebesar 0,444 yang berarti pengaruh variabel bebas rekrutmen terhadap variabel kinerja karyawannya adalah sebesar $44,4 \%$.

2. Besarnya nilai korelasi/hubungan antara kompensasi terhadap kinerja karyawan (R) yaitu sebesar 0,745 dimana diperoleh koefisien determinasi $\left(\mathrm{R}^{2}\right)$ sebesar 0,555 yang berarti pengaruh variabel bebas kompensasi terhadap variabel kinerja karyawannya adalah sebesar $55,5 \%$.

3. Besarnya nilai korelasi/hubungan antara rekrutmen dan kompensasi terhadap kinerja karyawan $(\mathrm{R})$ yaitu sebesar 0,799 dimana diperoleh koefisien determinasi $\left(\mathrm{R}^{2}\right)$ sebesar 0,638 yang berarti pengaruh variabel bebas rekrutmen dan kompensasi terhadap variabel kinerja karya-wannya adalah sebesar $63,8 \%$. Sisanya $36,2 \%$ dipengaruhi oleh faktor-faktor lainnya.

\section{B. Saran}

Berdasarkan kesimpulan di atas, maka penulis mengajukan beberapa saran yang diharapkan dapat bermanfaat bagi PT. Sinergi Inti Pelangi yaitu sebagai berikut :

1. Pimpinan perlu meningkatkan lagi untuk mekanisme perekrutan terutama dalam hal memilih kandidat yang sesuai dengan hasil tes kesehatan (medical check up) karena berdasarkan hasil distribusi kuesioner rekrutmen $34 \%$ tidak setuju dan sangat tidak setuju bahwa hal tersebut sudah berjalan dengan baik. Dengan demikian rules atau flow yang sudah di tetapkan dapat dijalankan sesuai dengan SOP-nya. Jika diperlukan maka SOP dapat direvisi agar sesuai dengan apa yang diharapkan.

2. Pimpinan perlu memperhatikan kesejah-teraan karyawannya terutama dalam hal salary (gaji) dan memberikan benefit yang sesuai dengan ketentuan pemerintah pada umumnya. Berdasarkan hasil distribusi kuesioner kompensasi sebanyak $34 \%$ tidak setuju dan sangat tidak setuju jika salary (gaji) yang diberikan ke karyawan sudah sesuai dengan Upah Minumum Provinsi. Hasil jawaban res-ponden juga menunjukkan bahwa pemimpin atau atasan diharapkan memperhatikan apa yang sudah di tentukan salah satunya terkait dengan overtime atau lembur, jika memang ada pekerjaan yang belum selesai maka kewajiban pekerja di haruskan lembur. Dengan begitu hak dan tanggung jawab antara pekerja dan perusahaan dapat berjalan dengan baik dan seimbang 
3. Diharapkan pimpinan dan manajemen, khususnya HRD dapat secara bersama-sama memperhatikan mekanisme yang baik dalam hal perekrutan dan memberikan kompensasi dan benefit sesuai dengan UndangUndang No. 13 tahun 2003 serta SK Gubernur terkait dengan Upah Minimum Provinsi atau Upah Minum Kota/Kabupaten. Begitu pula dengan perhitungan lembur harus berdasarkan perhitungan undang-undang ketenagakerjaan.

\section{DAFTAR PUSTAKA}

Algifari. (2010). Analisis Regresi Teori, Kasus dan Solusi Edisi Kedua. BPFE. Yogyakarta.

Bangun, Wilson. (2012). Manajemen Sumber Daya Manusia. Erlangga. Bandung

Ghozali, Imam. (2016). Aplikasi Analisis Multivariate Dengan Ibm Spss 23. Edisi 8. BP Universitas Diponegoro. Semarang

Fitri, Yunita S. (2010). Manajemen Personalia dan Sumber Daya Manusia . Yogyakarta: BPFE.

Handoko, Hani. (2010). Manajemen Personalia dan Sumber Daya Manusia. Yogyakarta: BPFE UGM Yogyakarta.

Handoko, Hani. (2013). Manajemen Personalia dan Sumber Daya Manusia. BPFE. Yogyakarta

Hasibuan, Malayu. (2017). Manajemen Sumber Daya Manusia. PT. Bumi Aksara. Jakarta.

L. Gaol, Jimmy. (2014). A to Z Human Capital Manajemen Sumber Daya Manusia. Kompas Gramedia. Jakarta.

Mangkunegara, Anwar Parbu. (2013). Manajemen Sumber Daya Manusia Perusahaan. Remaja Rosdakarya. Bandung.
Mangkuprawira, Sjafri. (2011). Manajemen Sumber Daya Manusia Strategik. Ghalia Indonesia. Bogor.

Mathis, Robert L., Jackson, John H. (2011). Human Resource Management (Manajemen Sumber Daya Manusia). Salemba Empat. Jakarta.

Mathis, Robert L., Jackson, John H. (2010). Manajemen Sumber Daya Manusia, Salemba Empat. Jakarta.

Mathis, Robert L., Jackson. (2011). Evaluasi Kinerja SDM. Salemba. Empat. Jakarta.

Moekijat. (2010). Manajemen Sumber Daya Manusia. Mandar Maju. Bandung

Sugiyono. (2013). Statistika Untuk Penelitian. Alfabeta. Bandung

Notoatmodjo, S. (2009). Pengembangan Sumber Daya Manusia. Rineka Cipta. Jakarta

Sarinah dan Mardalena. (2017). Pengantar Manajemen. CV. Budi Utama. Yogyakarta.

Samsudin, H, Sadeli. (2010). Manajemen Sumber Daya Manusia. Pustaka Setia. Bandung.

Siagian. (2011). Manajemen Sumber Daya Manusia. PT. Bumi Aksara. Jakarta.

Sedarmayanti. 2017. Manajemen Sumber Daya Manusia : Reformasi Birokrasi dan Manajemen Pegawai Negeri Sipil, PT. Refika Aditama. Bandung.

Sugiyono. (2016). Metode Penelitian Kuantitatif, Kualitatif dan R\&D. Alfabeta. Bandung.

Sugiyono. (2016). Metodologi Penelitian Kuantitatif, Kualitatif, dan R\&D. Cetakan Kedua Tiga. Alfabeta. Bandung.

Sugiyono. (2015). Metode Penelitian Kombinasi (Mix Methods). Bandung. Alfabeta. 
Sunarsi, D. (2018). Pengaruh Rekrutmen, Seleksi Dan Pelatihan Terhadap Produktivitas Kerja Karyawan. Kreatif: Jurnal Ilmiah Prodi Manajemen Universitas Pamulang, 6(1), 14-31.

Supardi. (2013). Aplikasi Statistika dalam Penelitian Konsep Statistika yang Lebih Komprehensif. Change. Publication. Jakarta.

Sutrisno, Edi. (2013). Manajemen Sumber Daya Manusia. Kencana Prenana Media Group. Jakarta,

Umam, Khaerul. (2010). Perilaku Organisasi. Bandung: Pustaka Setia

Veithzal Rivai Zainal, Mansyur Ramly, Thoby Mutis, Willy Arafah. (2014). Manajemen Sumber Daya Manusia untuk Perusahaan : dari Teori ke Praktik. Edisi Ketiga, Raja Grafindo Persada. Jakarta.

Veithzal Rivai, Sagala, Ella Juavani. (2013) Manajemen Sumber Daya Manusia untuk Perusahaan dari Teori ke Praktik. Cetakan Pertama. PT Raja Grafindo Persada. Jakarta.

Wibowo. (2014). Manajemen Kinerja, PT. RajaGrafindo Persada. Jakarta.
Wirawan. (2012). Evaluasi Kinerja Sumber Daya Manusia Teori. Aplikasi, dan Penelitian. Salemba Empat. Jakarta.

\section{Daftar Jurnal}

Artawijaya, I.G.P.A,. and Darma, G.S. (2015). Evaluation The Effectivity of Performance Management Online System to Improving The Employees Performance, 12 (2): $\mathrm{h}: 73-89$. Jurnal Manajemen dan Bisnis

Dwihatmojo. (2016). Rekrutmen, Pelatihan, dan Pembagian Kerja engaruhnya terhadap Kinerja Karyawan pada C. Jati Jaya Meubel Amurang, 4(1). Jurnal EMBA

Effendi, S. (2014). Pengaruh Seleksi dan Pelatihan terhadap Kompetensi serta Dampaknya pada Kinerja Karyawan. 9(17). Jurnal Manajemen dan Bisnis Aliansi

Purnantara, I.M.H., and Darma, G.S. (2015). Comptenecy, Organizational Health, Job Career, Job Performance and Employees Turnover. 12(2): h: 90-124. Jurnal Manajemen dan Bisnis. 